\title{
Seasonal changes in circulating gonadal steroid levels and physiological evidence for the presence of intrinsic circannual reproductive cycles in captive finless porpoises Neophocaena asiaeorientalis from the western Inland Sea, Japan
}

\author{
Noriko FUNASAKA ${ }^{1)}$, Motoi YOSHIOKA ${ }^{1)}$, Toshiaki ISHIBASHI ${ }^{2,5)}$, Toshiyuki TATSUKAWA ${ }^{2,5)}$, \\ Hideaki SHINDO ${ }^{2,5)}$, Koji TAKADA ${ }^{3,5)}$, Masayuki NAKAMURA ${ }^{3,5)}$, Tomohiko IWATA ${ }^{3,5)}$, \\ Kaoru FUJIMARU ${ }^{3,5)}$ and Taira TANAKA ${ }^{4,5)}$ \\ 1) Cetacean Research Center, Graduate School of Bioresources, Mie University, Mie 514-8507, Japan \\ 2) Shimonoseki Marine Science Museum, Yamaguchi 750-0036, Japan \\ 3) MARINE WORLD uminonakamichi, Fukuoka 811-0321, Japan \\ 4) Oita Marine Palace Aquarium UMITAMAGO, Oita 870-0802, Japan \\ 5) Species Management Committee for Finless Porpoises of the Western Inland Sea, Fukuoka 811-0321, Japan
}

\begin{abstract}
We monitored annual fluctuations of gonadal steroid levels in three sexually mature captive finless porpoises (Neophocaena asiaeorientalis; two males and one female) from two different facilities over 56-91 months. Two animals (one male and one female) were held in an indoor tank with a sunroof (facility A) and the other male was held in an indoor tank without a sunroof (facility B). Water temperatures in both facilities reflected seasonal changes during the study period with a minor difference in the fluctuation pattern. Testosterone levels of the male in facility A were higher from spring to summer every year and exhibited a 12-month cycle. The female showed estrus cycles in 1-month intervals from summer to winter, excluding 2 anestrus years. In contrast, the period of higher testosterone levels of the male in facility B gradually initiated earlier over the years under a constant photoperiod (11.5L:12.5D) and exhibited a 9-month cycle during the first 52 months. After changing the light conditions to a natural photoperiod, its testosterone levels were high from early spring to summer for 3 consecutive years and exhibited a 12-month cycle. Our results showed that under a constant artificial photoperiod, the male in facility B failed to recognize the seasonal changes of a natural external environment, resulting in a 9-month, free-running hormone cycle.
\end{abstract}

Key words: Constant photoperiod, Free-running, Neophocaena asiaeorientalis, Progesterone, Testosterone

(J. Reprod. Dev. 64: 145-152, 2018)

$\mathbf{M}$ ammals are found throughout the world, from the tropics to the arctic regions. Many mammals live in environments with seasonal fluctuations in climate and food availability, and these fluctuations are more pronounced with increased latitude [1]. Most mammals have developed adaptive strategies to synchronize reproduction with annual changes in the environment, such as photoperiod and temperature. Seasonal breeding is necessary for successful reproduction during optimal conditions as it ensures food availability for optimal neonate growth to support independent survival [1].

Seasonal reproduction in many cetacean species has been described and mostly demonstrated by endocrinological monitoring [2, 3]. Serum and plasma levels of gonadal steroids provide valuable information for evaluating reproductive activity of small cetaceans [4]. Testosterone

Received: June 15, 2017

Accepted: December 20, 2017

Published online in J-STAGE: January 19, 2018

C)2018 by the Society for Reproduction and Development

Correspondence: M Yoshioka (e-mail: motoi@bio.mie-u.ac.jp)

This is an open-access article distributed under the terms of the Creative Commons Attribution Non-Commercial No Derivatives (by-nc-nd) License. (CC-BY-NC-ND 4.0: https://creativecommons.org/licenses/by-nc-nd/4.0/) and progesterone levels are good indicators for assessing testicular and ovarian activities of captive dolphins, such as white whales (Delphinapterus leucas) [5], common bottlenose dolphins (Tursiops truncatus) [6-10], Pacific white-sided dolphins (Lagenorhynchus obliquidens) [11], and killer whales (Orcinus orca) [12]. Indoor rearing of cetaceans has increased, although little is known about the effects of indoor environments on reproductive seasonality of captive animals. It is generally accepted that seasonal photoperiods and water temperatures are crucial factors that regulate seasonal breeding in mammals [1]. Therefore, it would be beneficial for captive breeding and health management practices to understand the physiological mechanisms of regulating cetacean seasonal activities and the annual reproductive activity of captive cetaceans.

Finless porpoises (Neophocaena asiaeorientalis) are considered seasonal breeders and occur in temperate coastal waters of the western Pacific Ocean from the Taiwan Strait northwards to Korea and central Japan $[13,14]$. In Japan, morphological and genetic studies have indicated at least five different populations of this species, Sendai-Tokyo Bays, Ise-Mikawa Bays, Inland Sea-Hibiki Nada, Omura Bay, and Ariake Sound-Tachibana Bay $[15,16]$. Some studies investigated the life histories of the Inland Sea, Ise Bay, and 
Table 1. Description of mature finless porpoises used and environmental conditions during the study

\begin{tabular}{|c|c|c|c|c|c|c|c|}
\hline Facility & Animal $\#$ & Sex & $\begin{array}{l}\text { Date of introduction } \\
\text { into the facility }\end{array}$ & $\begin{array}{l}\text { Body length } \\
(\mathrm{cm})^{1)}\end{array}$ & $\begin{array}{l}\text { Sampling } \\
\text { period }\end{array}$ & Photoperiod & $\begin{array}{l}\text { Other individuals kept } \\
\text { in the same tank }\end{array}$ \\
\hline A & M1 & Male & Dec 1998 & $149-160$ & $\begin{array}{l}\text { Apr 2005- } \\
\text { Nov } 2011\end{array}$ & Natural & \multirow{2}{*}{$\begin{array}{l}\text { One female (F2) and one male (M3) } \\
\text { F2: Sep 2007 } 2 \text { ) } 100 \mathrm{~cm}^{3)} \text {, matured in 2011 } \\
\text { M3: Jan } 2009,120 \mathrm{~cm} \text {, matured in } 2012\end{array}$} \\
\hline A & F1 & Female & Mar 1992 & $157-155$ & $\begin{array}{l}\text { Apr 2005- } \\
\text { Dec 2009 }\end{array}$ & Natural & \\
\hline B & M2 & Male & May 2001 & $159-174$ & $\begin{array}{l}\text { Apr 2005- } \\
\text { Nov } 2012\end{array}$ & $\begin{array}{l}\text { Constant (from beginning of } \\
\text { the study to August 2009) } \\
\text { Natural (from Sep. } 2009 \text { to } \\
\text { end of the study) }\end{array}$ & $\begin{array}{l}\text { Two females (F3, F4) and one male (M4) } \\
\text { F3: May 2006, } 106 \mathrm{~cm} \text {, immature } \\
\text { F4: Sep 2011, } 103 \mathrm{~cm} \text {, immature } \\
\text { M4: Sep 2010, } 116 \mathrm{~cm} \text {, matured in } 2012\end{array}$ \\
\hline
\end{tabular}

A: MARINE WORLD uminonakamichi, Fukuoka, Japan; B: Shimonoseki Marine Science Museum, Yamaguchi, Japan. ${ }^{1)}$ From the beginning of the study to the end of the study. ${ }^{2)}$ Date of introduction to the facility. ${ }^{3)}$ Body length during introduction to the facility. ${ }^{4)}$ Timing of the attainment of sexual maturity during the study period was defined by hormone analysis.

western Kyushu populations [17-20]; based on gonadal anatomy and behavioral observations, April was estimated as the peak parturition season for Inland Sea and Ise Bay populations [17, 19], whereas a prolonged autumn to spring parturition was estimated for the western Kyushu population [20]. Although several methods have demonstrated the seasonality of a few finless porpoise populations, gonadal physiological changes remained unclear.

In the present study, we monitored testosterone and progesterone levels in serum and plasma of captive, sexually mature male and female finless porpoises from the western Inland Sea of Japan that were reared in two separate indoor facilities with different environmental conditions. Our aims were to characterize annual fluctuations in the breeding season and to discuss mechanisms of seasonal control in porpoises by examining the relationships between gonadal steroid fluctuations and external environmental conditions.

\section{Material and Methods}

\section{Experimental ethics}

This study was conducted following the Guidelines for Animal Experiments of the Faculty of Bioresources, Mie University. All finless porpoises in the aquariums were treated accordingly and within the scope of the experimental procedures. Member aquariums of the Japanese Association of Zoos and Aquariums (JAZA) are in compliance with the "Law Concerning the Protection and Control of Animals" and "Care and Feeding Standards for Display Animals" established by the Ministry of the Environment in Japan. All blood samples obtained from porpoises were collected using routine husbandry protocols or captured using a stretcher and a few minutes of animal restriction.

\section{Animals and captive environment conditions}

Three sexually mature finless porpoises housed in two different aquariums were used for our experiments. One male [M1, JAZA Studbook Number (JAZA SB\#) 57] and one female (F1, JAZA SB\# 47) were held in facility A (MARINE WORLD uminonakamichi, Fukuoka, Japan, $33.65^{\circ} \mathrm{N}$ latitude), while one male (M2, JAZA SB\# 68 ) was held in facility B (Shimonoseki Marine Science Museum, Yamaguchi, Japan, $33.95^{\circ} \mathrm{N}$ latitude; Table 1). They were held in indoor tanks (facility A: $60.0 \mathrm{~m}^{3}$ capacity, $6.4 \mathrm{~m}$ wide, $4.9 \mathrm{~m}$ long,
$2.0 \mathrm{~m}$ deep; facility B: $163.3 \mathrm{~m}^{3}$ capacity, $8.2 \mathrm{~m}$ wide, $7.1 \mathrm{~m}$ long, $3.6 \mathrm{~m}$ deep). All porpoises were taken into captivity from Genkainada and Suo-nada of the western Inland Sea and remained healthy throughout the study. All porpoises were sexually mature at the start of the study based on hormonal analysis performed by each facility. They were kept with other porpoises during the middle of the study period (Table 1). M1 and F1 received $1.5-3.2 \mathrm{~kg}$ /day of a diet comprising of horse mackerels, mackerels, capelins, and smelts. M2 received 2.6-3.6 kg/day of horse mackerels, mackerels, capelins, smelts, Pacific herring (Clupea pallasii), Japanese anchovy (Engraulis japonicus), Pacific saury (Cololabis saira), prawns, and squids. Diets were regulated according to the season and health conditions of the porpoises.

Light conditions for both facilities were determined based on the opening hours of the aquariums (Fig. 1). In facility A, lighting times were from 0830 to $1800 \mathrm{~h}$ from March to November and from 0900 to $1730 \mathrm{~h}$ from December to February. In facility B, lighting times were $11.5 \mathrm{~h}(0800$ to $1930 \mathrm{~h})$, although this increased during aquarium peak periods. The sunroof in the tank room of facility A provided sunlight throughout the study period. The tank room in facility B possessed no windows; therefore, M2 was exposed to a controlled photoperiod (11.5L:12.5D) using artificial illumination (mercury lamp, approximately $4000 \mathrm{~lx}$ ). In facility B, light conditions were altered to reflect the natural photoperiod of Yamaguchi Prefecture after September 2009. Monthly average water temperatures in the tanks ranged from $13.1^{\circ} \mathrm{C}$ to $27.5^{\circ} \mathrm{C}$ in facility $\mathrm{A}$ and from $15.9^{\circ} \mathrm{C}$ to $25.0^{\circ} \mathrm{C}$ in facility B (Fig. 1), exhibiting seasonal changes in both facilities during the study period with minor differences in the fluctuation pattern.

\section{Blood sampling}

Blood sampling was performed biweekly or monthly from April 2005 to November 2011 (79 months) for M1, from April 2005 to December 2009 (56 months) for F1, and from April 2005 to November 2012 (91 months) for M2. Blood samples from M1 and $\mathrm{F} 1$ in facility A were collected from tail fluke veins while each animal was stationed at the poolside at approximately $1700 \mathrm{~h}$. Samples from M2 in facility B were collected from the tail fluke vein while the animal was held on a stretcher (performed until August 2006) or using a husbandry blood-sampling method (performed after September 


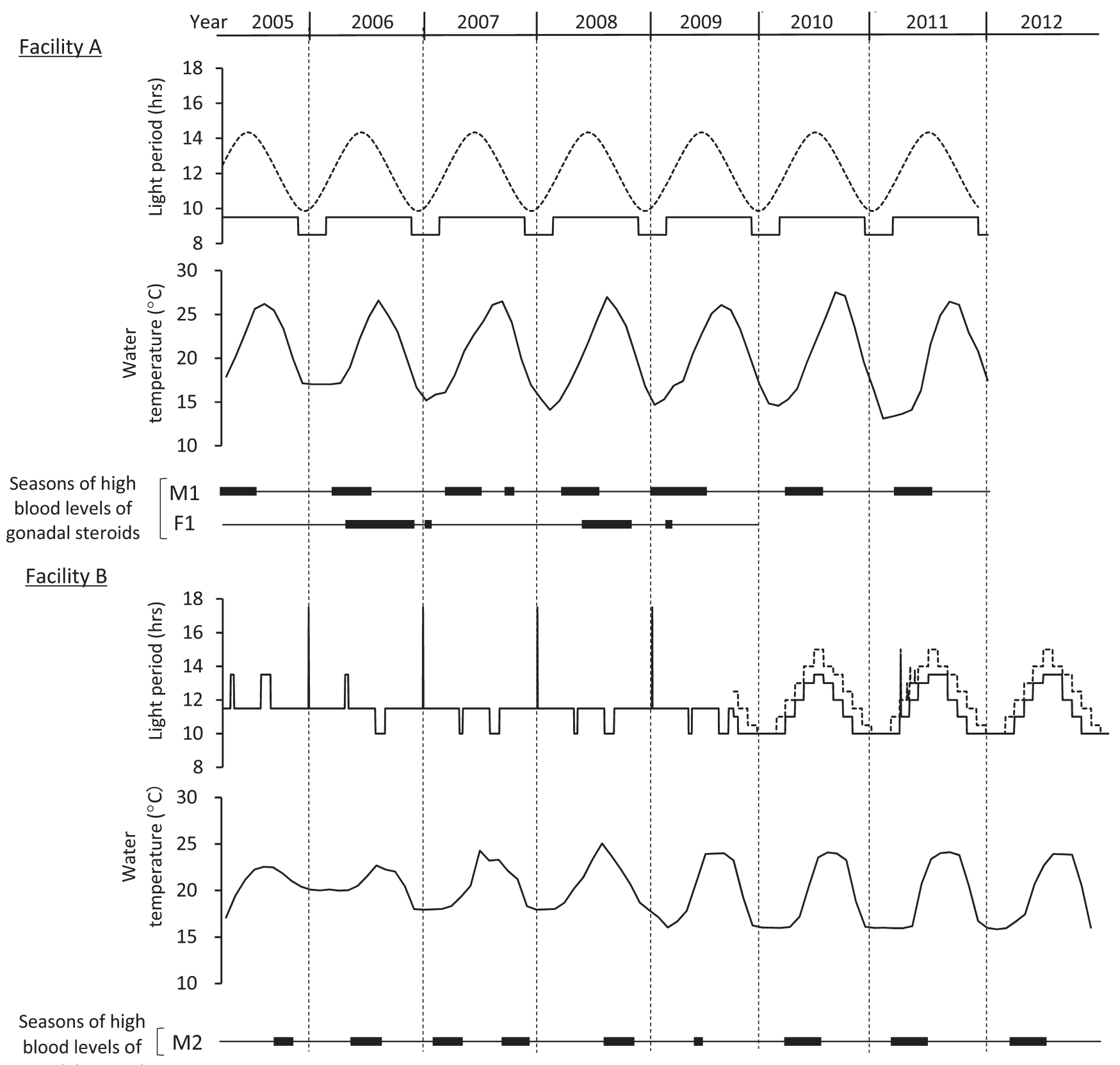

gonadal steroids

Fig. 1. Correlation of environmental conditions (indoor light period and water temperature) of two facilities with serum and plasma gonadal steroid levels of finless porpoises throughout the study period. The dashed line in the graph of facility A indicates the natural photoperiod in Fukuoka Prefecture $\left(33.65^{\circ} \mathrm{N}\right.$ latitude) and twilight (about $50 \mathrm{~lx}$ or less) by fluorescent light in facility B. Bold horizontal bars indicate periods of high gonadal steroid levels (males M1 and M2, testosterone levels $>5 \mathrm{ng} / \mathrm{ml}$; female F1, progesterone levels $>3 \mathrm{ng} / \mathrm{ml}$ ), and narrow bars indicate low gonadal steroid levels.

2006) at approximately $0900 \mathrm{~h}$. Plasma from M1 and F1 and serum or plasma from M2 were separated by centrifugation (3,000 rpm, $15 \mathrm{~min}$ ) and stored at $-30^{\circ} \mathrm{C}$ until hormone analyses. Most of the plasma and serum samples used in this study were the remainder of the samples obtained for routine health assessment in each facility.

\section{Hormone assays}

Serum and plasma testosterone levels were determined following an enzyme immunoassay method validated for use with dolphins by Kita et al. [21]. Assay sensitivity for testosterone was $0.1 \mathrm{ng} / \mathrm{ml}$. Levels of serum and plasma progesterone were determined using a commercial enzyme immunoassay kit manufactured by Neogen 
Corporation (low-levels: Progesterone Ultra Kit \#402410, 0.1-2 ng/ $\mathrm{ml}$; high-levels: Progesterone Kit \#402310, 0.4-40 ng/ml) following manufacturer's instructions.

\section{Data analysis}

Autocorrelation coefficients were used to analyze seasonal periodicity of testosterone levels. Statistical analyses were performed using the Ekuseru-Toukei 2012, Excel add-in software (Social Survey Research Information, Tokyo, Japan).

\section{Results}

Serum and plasma gonadal steroid levels of two male and one female finless porpoises showed distinctive seasonal changes throughout the study period (Figs. 2 and 3).

For M1, plasma testosterone levels ranged from $<0.1$ (detection limit of the assay) to $98.5 \mathrm{ng} / \mathrm{ml}$. Periods with testosterone levels $>5$ $\mathrm{ng} / \mathrm{ml}$ - high levels during the breeding season of finless porpoises in the Yangtze River [22] — occurred from March to July of each year coinciding with changes in photoperiod and water temperature of facility A(Figs. 1 and 2); there were a few exceptions during October 2007 and January 2009 around the same time when new porpoises were introduced into the tank (Table 1). Based on autocorrelation coefficient determinations, the cycle of plasma testosterone was 12 months ( $\mathrm{P}<0.05$; Fig. 4).

For M2, annual testosterone profiles recorded until August 2008 were different from those found for M1. Under a constant photoperiod, periods of testosterone levels $>5 \mathrm{ng} / \mathrm{ml}$ were gradually initiated earlier over the years; for example, August to September in 2005, May to August in 2006, January to March in 2007, and October to December in 2007 (Figs. 1 and 2). These fluctuations in testosterone levels were considerably different from the changes observed for the photoperiod and water temperature of facility B. The cycle of serum and plasma testosterone until August 2008 was 9 months $(\mathrm{P}<0.05)$, shorter than that of M1 (Fig. 4). After light conditions were changed to a natural photoperiod in facility B in September 2009, the serum and plasma testosterone levels of M2 increased from February to June during 2010-2012 (Fig. 2) with a cycle of 12 months $(\mathrm{P}<0.05)$, similar to that of M1 (Fig. 4). Serum and plasma testosterone levels after changing to a natural photoperiod (maximum $117.9 \mathrm{ng} / \mathrm{ml}$ ) were higher than the levels obtained at a constant photoperiod (maximum $59.0 \mathrm{ng} / \mathrm{ml}$ ) and were particularly high in 2011.

To examine if the increase in serum and plasma testosterone levels of M1 and M2 was in response to the changes in photoperiod or water temperature, the period in days from the commencement of the change to the increase in testosterone levels under natural photoperiods was calculated (Table 2); this period was not significantly different between M1 and M2 ( $>0.05$, Student's $t$-test). The coefficient of variation of days from the increase in photoperiod between the years (8.1) was the lowest among the change in environmental cues (Table 2).

For F1, progesterone levels ranged from $<0.1$ to $20.7 \mathrm{ng} / \mathrm{ml}$. Periods where progesterone levels were $>3 \mathrm{ng} / \mathrm{ml}$ - presumptive evidence of luteal activity in dolphins [6] - occurred from June to November during 2006 and 2008 (Figs. 1 and 3). Progesterone levels returned to basal levels $(<1 \mathrm{ng} / \mathrm{ml})$ approximately 1 month after their increase, although limited samples were collected in November
2006 and from November to December 2008. These cyclic rises of progesterone occurred at approximately 1-month intervals.

\section{Discussion}

In the present study, serum and plasma levels of gonadal steroids from three sexually mature finless porpoises were monitored over 5 to 8 years in two different facilities with different external environmental conditions. Seasonal differences in serum and plasma levels were observed in all three animals. Based on changes in testosterone levels, a hormonal study of a captive finless porpoise male from the Yangtze River [23] proposed that the breeding season is from March to September, with its peak from April to July. Hao et al. [22] reported that serum and plasma testosterone levels in males were significantly higher in March and April than in October and December in wild finless porpoises from the Yangtze River, although progesterone levels in females showed no significant seasonal differences - possibly due to the limited number of samples. Since the parturition season for finless porpoises in the Inland Sea is from April to August [20] and the gestation period lasts approximately 11 months [18], the conception season in the Inland Sea is considered to be between March and July. In the case of the three porpoises taken into captivity from the western Inland Sea, M1 and F1 exhibited high gonadal steroid levels from spring to summer and from summer to winter during the same season each year, in contrast to M2 (prior to 2009). Therefore, the breeding season for M1 was similar to that of wild finless porpoises in the Inland Sea and its testicular activity was thought to exhibit the closest seasonality to wild porpoises among the three porpoises in the present study. In addition, the testosterone variation profile of M1 was consistent with sonographic morphology changes of the testis (Fujimaru et al., unpublished results).

Annual testosterone profiles of M2 differed each year until August 2009 , unlike that of M1. The period of high testosterone levels of M2 gradually occurred earlier over the years with a cycle of 9 months, whereas the testosterone profiles of M1 exhibited high levels during the same season each year with a cycle of 12 months. Cyclic increases in plasma progesterone levels of $\mathrm{F} 1$ were also observed from summer to winter. These individual differences in cycle lengths of testosterone and progesterone may be a result of different external environmental factors associated with the construction of each facility. The tank room in facility A, in which M1 and F1 were kept, had a sunroof and the porpoises were exposed to natural photoperiods during the entire study period. In contrast, the tank room in facility B, in which M2 was held, had no windows and the porpoise was exposed to a nearly constant photoperiod throughout the year, depending only on artificial illumination. Water temperatures exhibited seasonal changes in both facilities during the study period, but they were not the same as those of natural environments. Due to the shift in light conditions of facility B to a natural photoperiod after September 2009, M2 testosterone cycles increased from 9 to 12 months. These results suggest that M2 during artificial illumination failed to recognize seasonal changes via natural environmental cues and exhibited a 9-month, free-running spermatogenesis cycle.

The seasonality of reproductive activity and other physiological phenomena observed in most mammals is presumed to arise from an interaction between endogenous circannual rhythms and 


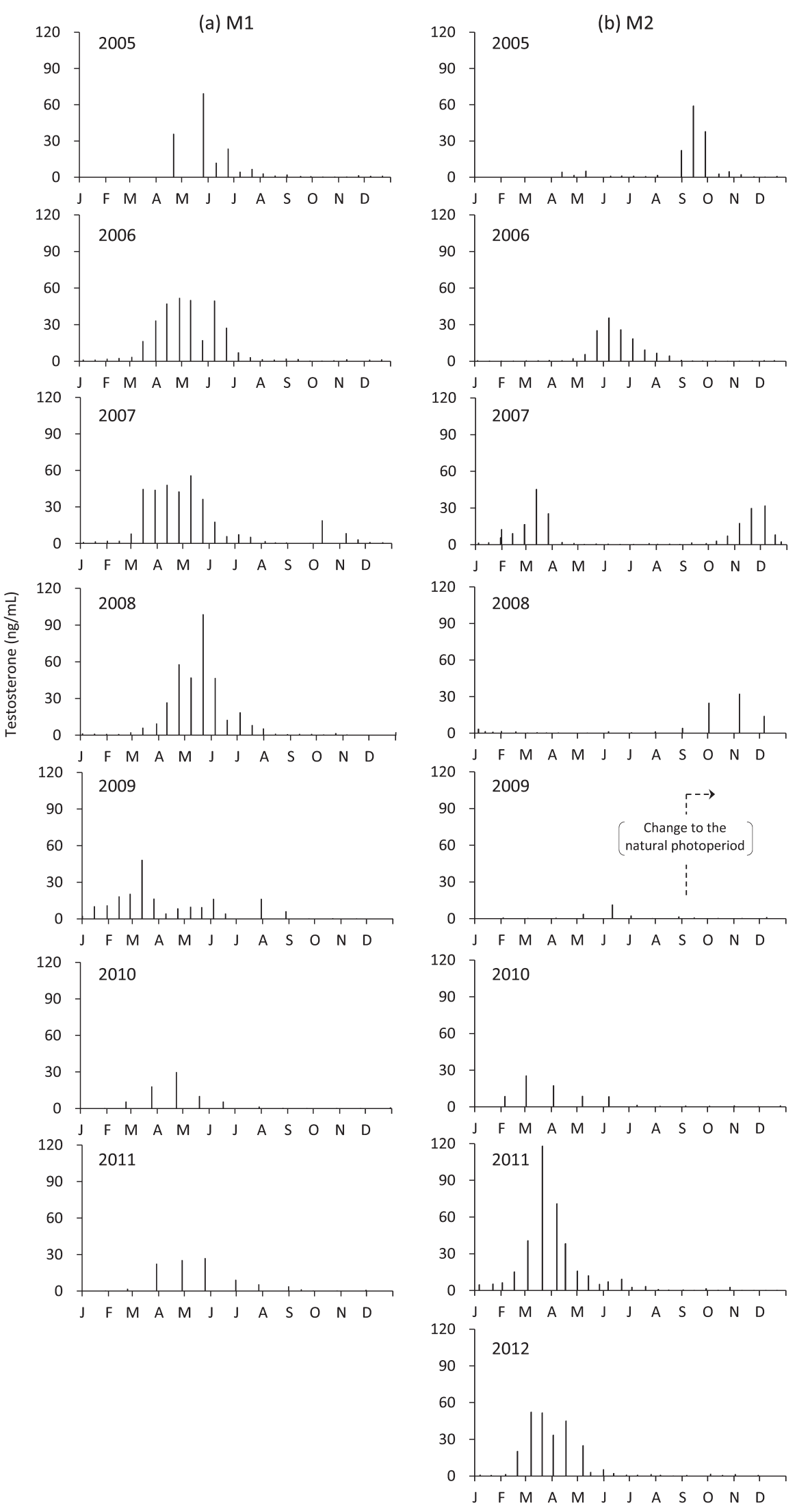

Fig. 2. Annual changes in serum and plasma testosterone levels in two sexually mature male finless porpoises (M1 and M2). The arrow indicates the timing of photoperiod changes from constant to natural. 


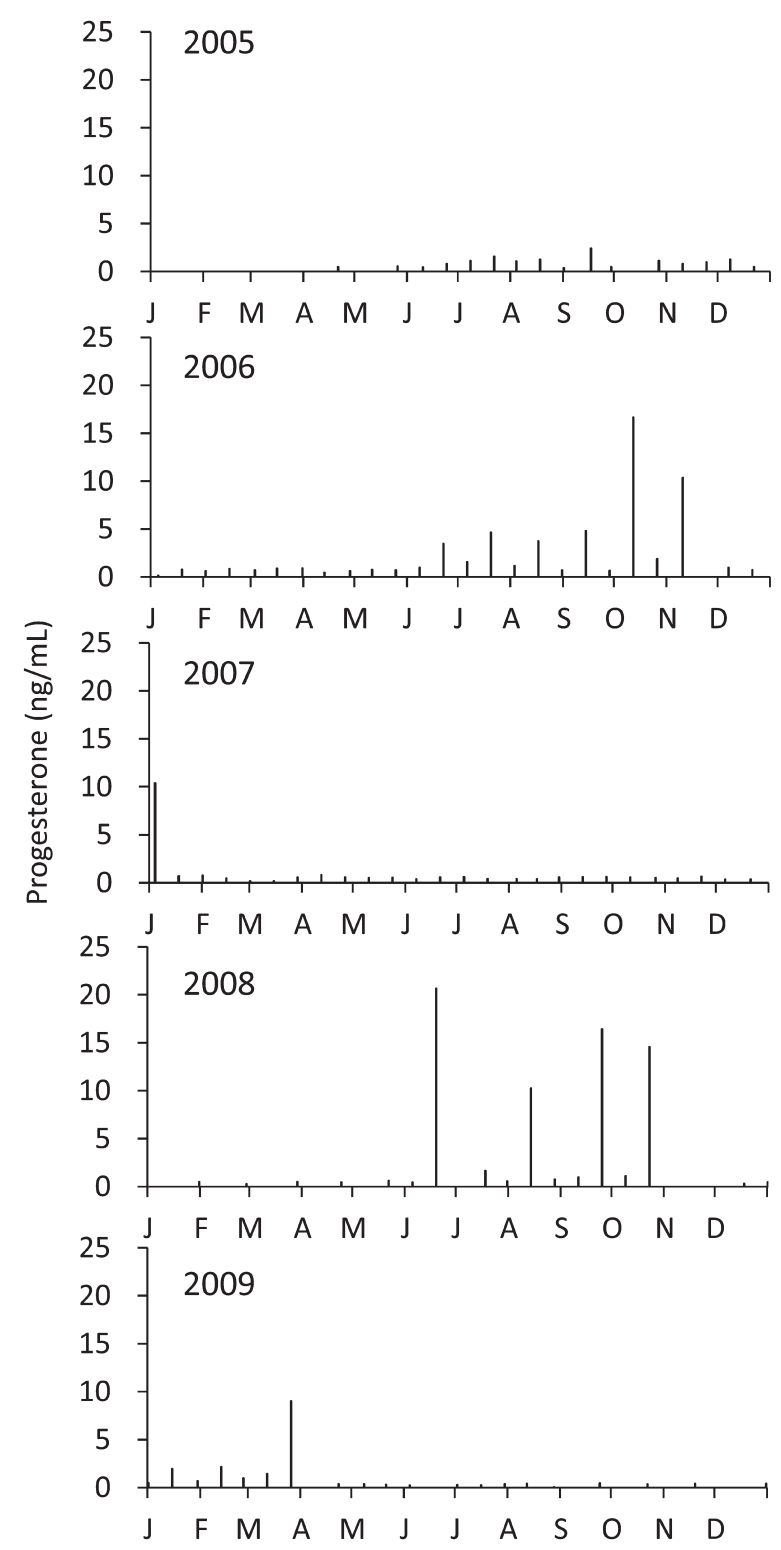

Fig. 3. Annual changes in serum and plasma progesterone levels of the female finless porpoise (F1) from April 2005 to December 2009.

environmental changes $[24,25]$. Under constant conditions without seasonal information, these rhythms persist with an endogenous period close to 1 year, i.e., free-running and entrainment to an annual cycle under natural conditions [24, 26, 27]. Free-running circannual reproductive cycles under a constant light condition of 12L:12D have been reported for various mammalian species; the cycle of blood testosterone and progesterone levels in the woodchuck Marmota monax was reported to be approximately 10 months [28], that for blood progesterone levels in Suffolk ewes was approximately 10 months [29], and that for testis development in the tropical bat Anoura geoffroyi was approximately 7 months [30]. These cycles are considerably shorter than 12 months and closer to the 9-month cycle

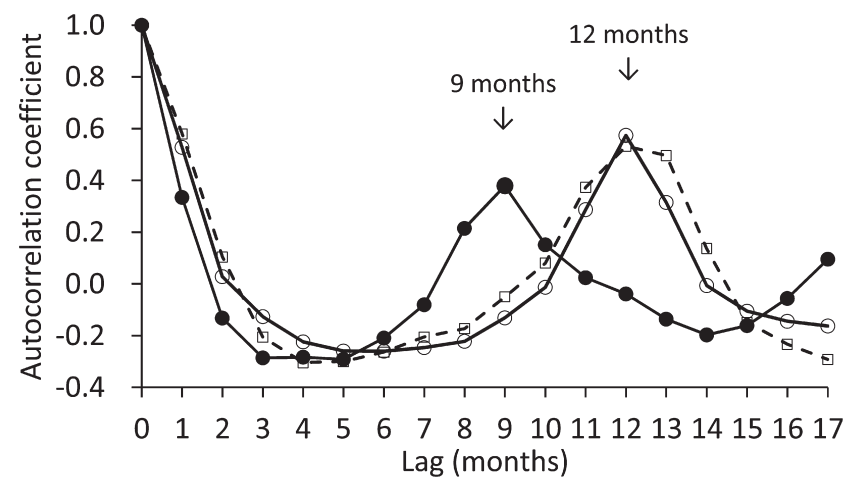

Fig. 4. Autocorrelation of serum and plasma testosterone levels of two male finless porpoises. Dashed lines and squares indicate the autocorrelation coefficient of M1 throughout the study period. Solid lines and circles indicate the autocorrelation coefficient of M2 before changing the photoperiod, while solid lines and open circles represent the autocorrelation coefficient after changing the photoperiod.

observed for M2 in the present study. Therefore, finless porpoises are considered to have an intrinsic circannual rhythm to measure time for seasonal adaptations.

Photoperiods are considered the main trigger for synchronizing annual reproductive cycles in mammals [31, 32]. In captive finless porpoises from the Yangtze River, Yu et al. [33] showed that enhanced testicular sonographic appearance and increased sexual behaviors in response to extended photoperiods. Variation in physiological responses to environmental zeitgebers of circannual rhythms, such as photoperiod and temperature, should be consistent [24] and individual differences must be minimal. In the present study, the variation of the period (in days) from initiating an increase in the photoperiod to the increase in serum and plasma testosterone levels between the years was the lowest among the environmental cue changes; therefore, the zeitgeber that controls circannual rhythms is likely to be changes in photoperiods. The seasonality in mammals is believed to be regulated by melatonin secreted by the pineal gland and entrained by photoperiods [32, 34]; however, the pineal gland is known to be reduced or even lacking in cetaceans [35]. An absence of significant diurnal rhythms of melatonin was observed in Indo-Pacific bottlenose dolphins (Tursiops aduncus) [36]. Although a cautious discussion regarding the mechanism of this seasonality is required, extra-pineal melatonin production by the retina, Harderian gland, and gut has been analyzed in common bottlenose dolphins [37]. Nevertheless, data obtained from the present study on finless porpoises are consistent with the results of experimentally-induced testicular activity in response to extended photoperiods in captive finless porpoises [33]. Furthermore, the data suggest that photoperiods are a crucial factor for reproduction, implying strong regulation by melatonin secreted by pineal or extra-pineal glands.

Water temperatures exhibited seasonal changes in both facilities during the study period with a range of approximately $10^{\circ} \mathrm{C}$. Since water temperature seasonal changes were observed in facility B even before changing the light conditions, it is unlikely that circannual testosterone rhythms of $\mathrm{M} 2$ responded to changes in water temperature. 
Table 2. Comparison of the coefficients of variation (CVs) for the period in days from the change in environmental cues to the rise in testosterone levels $(>5 \mathrm{ng} / \mathrm{ml})$ in two mature male finless porpoises (M1 and M2) under a natural photoperiod

\begin{tabular}{|c|c|c|c|c|c|}
\hline \multirow{3}{*}{ Animal \# } & \multicolumn{5}{|c|}{ Period in days from the commencement of change in environmental cues to the rise in testosterone levels in the following year ${ }^{1)}$} \\
\hline & \multirow{2}{*}{ Change in environmental cues } & \multicolumn{2}{|c|}{ Increase $^{2)}$} & \multicolumn{2}{|c|}{ Decrease $^{3)}$} \\
\hline & & Photoperiod & Water temperature & Photoperiod & Water temperature \\
\hline \multirow[t]{3}{*}{ M1 } & Mean \pm SD & $416 \pm 27$ & $353 \pm 43$ & $228 \pm 28$ & $188 \pm 22$ \\
\hline & Min.-Max. & $375-446$ & $308-400$ & $184-262$ & $154-213$ \\
\hline & $n^{4)}$ & 5 & 5 & 6 & 6 \\
\hline \multirow{3}{*}{$\begin{array}{l}\text { M2 } \\
\text { (after changing to the } \\
\text { natural photoperiod) }\end{array}$} & Mean \pm SD & $370 \pm 21$ & $313 \pm 16$ & $189 \pm 21$ & $131 \pm 47$ \\
\hline & Min.-Max. & $355-384$ & 309-331 & $174-203$ & $96-185$ \\
\hline & $\mathrm{n}$ & 2 & 3 & 2 & 3 \\
\hline \multirow[t]{3}{*}{ M1 and M2 } & Mean \pm SD & $402 \pm 33$ & $338 \pm 40$ & $218 \pm 31$ & $169 \pm 41$ \\
\hline & $\mathrm{n}$ & 7 & 8 & 8 & 9 \\
\hline & $\mathrm{CV}$ & 8.1 & 11.7 & 14.2 & 24.2 \\
\hline
\end{tabular}

1) The period in days until a rise in testosterone levels was observed in the following year was used because minimum or maximum photoperiod and water temperature levels occurred before a rise in testosterone levels in most cycles. ${ }^{2)}$ The day of commencement of an increase in environmental cues was defined as the day on which the photoperiod or water temperature was longer or higher, respectively, than the minimum value for three consecutive days and did not subsequently return to the minimum value. ${ }^{3)}$ The day of commencement of a decrease in environmental cues was defined as the day on which the photoperiod or temperature was shorter or lower, respectively, than the maximum value for three consecutive days and did not subsequently return to the maximum value. ${ }^{4)}$ Number of cycles calculated the period in days from the change in environmental cues to the rise in testosterone levels.

Although photoperiods are undeniably capable of being a zeitgeber with the strongest effects on animal internal rhythms, zeitgebers that synchronize internal cycles with the external environment also include temperature and social factors in birds and insects [27, 32]. Further studies are required to reveal the involvement of water temperature in the entrainment of circannual rhythms in finless porpoises. In facility B, M2 was kept under the natural photoperiod conditions from 2009 to 2012, and thus far, (August 2017) its breeding season has been annually occurring in the spring.

Cyclic rises in plasma progesterone levels of F1 were observed from the summer to winter seasons of 2006 and 2008. This was considered to reflect estrus cycles and ovulation for this species. The cycles occurred at approximately 1-month intervals, similar to the 36-day interval observed in common bottlenose dolphins [10] and the 31-day cycle of Pacific white-sided dolphins [11]. Although biweekly or monthly sampling interval of the female porpoise may have been inadequate and incapable of predicting estrus cycles, no progesterone increase was detected in 2005, 2007, and 2009, indicative of anestrus which has been reported in common bottlenose dolphins $[7,8]$. This suggests that estrus and ovulation did not always occur annually in our study.

In facility A, F1 experienced increases in progesterone from summer to winter, whereas M1 exhibited a rise in testosterone from spring to summer. This slight shift in seasonal reproductive activity between the sexes may also occur in terrestrial mammals and other cetacean species. For example, in Pacific white-sided dolphins, ovulation and conception occur from August to October, whereas monthly mean testosterone levels peak in July [11]. In Hokkaido brown bears (Ursus arctos yesoensis), peaks of copulation occur in May and June for females [38] while testosterone levels peak in April and May for males [39]. Timing and duration of the breeding season can be affected by interactions between the photoperiod and various other factors, such as temperature, nutritional status, and social interactions [1, 40]. Urian et al. [41] found that wildcaught, female common bottlenose dolphins that had experienced over five parturitions in an artificial environment retained the wild habitat seasonality for the duration of the study period. However, there was a tendency for parturition to occur slightly later in the season and there was also a large amount of variation in females, indicating that reproductive seasonality that occurs in the wild is retained for an extended period in captivity but may be gradually lost. In the present study, F1 was in captivity for the longest period compared with the other two porpoises (approximately 17 years); therefore, the prolonged ovarian activity observed may have been related to a decrease in environmental pressures (e.g., controlled water temperature) and good nutrition due to the stable food supply provided by captive conditions.

In conclusion, the breeding season of captive finless porpoises from the western Inland Sea of Japan was estimated to occur from spring to summer, based on changes in serum and plasma gonadal steroid levels. Results obtained in the present study demonstrate for the first time that finless porpoises possess an intrinsic circannual rhythm that measures time for seasonal adaptations. Furthermore, our results indicate the possibility of photoperiods playing a significant role in finless porpoise circannual reproductive cycles. Our data can contribute to improving indoor, captive environments to promote healthy and stable captive breeding programs for cetaceans in aquariums.

\section{Acknowledgments}

We would like to thank all the staff members of the Shimonoseki Marine Science Museum and MARINE WORLD uminonakamichi for their invaluable assistance in handling animals and sample collections. We would also like to thank Dr Y Morita and Ms S Danjo of Mie University for their cooperation with gonadal steroid measurements. This work was partly supported by the Sa- 
sakawa Scientific Research Grant from the Japan Science Society [\#18-281G, 2006].

\section{References}

1. Bronson FH. 1989. Mammalian Reproductive Biology. University of Chicago Press, New York.

2. Robeck TR, Atkinson SKC, Brook F. Reproduction. In: Dierauf LA, Gulland MD (eds.), CRC Handbook of Marine Mammal Medicine, Second ed. Boca Raton, Florida: CRC Press; 2001: 193-236.

3. Atkinson S, Yoshioka M. Endocrinology of reproduction. In: Jamieson BGM, Miller DL (eds.), Reproductive Biology and Phylogeny of Cetacea; Whales, Dolphins and Porpoises. New Hampshire: Science Publishers; 2007: 171-192.

4. Kirby VL. Endocrinology of marine mammals. In: Dierauf LA (ed.), CRC Handbook of Marine Mammal Medicine. Boca Raton, Florida: CRC Press; 1990: 303-351.

5. Robeck TR, Monfort SL, Calle PP, Dunn JL, Jensen E, Boehm JR, Young S, Clark ST. Growth and development in captive beluga (Delphinapterus leucas). Zoo Biol 2005; 24: 29-49. [CrossRef]

6. Sawyer-Steffan JE, Kirby VL, Gilmartin WG. Progesterone and estrogens in the pregnant and nonpregnant dolphin, Tursiops truncatus, and the effects of induced ovulation. Biol Reprod 1983; 28: 897-901. [Medline] [CrossRef]

7. Kirby VL, Ridgway SH. Hormonal evidence of spontaneous ovulations in captive dolphins, Tursiops truncatus and Delphinus delphis. Rep int Whal Commn (special issue 6) $1984 ; 459-463$.

8. Yoshioka M, Mohri E, Tobayama T, Aida K, Hanyu I. Annual changes in serum reproductive hormone levels in the captive female bottle-nosed dolphins. Bull Japan Soc Sci Fish 1986; 52: 1939-1946. [CrossRef]

9. Schroeder JP. Breeding bottlenose dolphins in captivity. In: Leatherwood S, Reeves RR (eds.), The Bottlenose Dolphin. San Diego: Academic Press; 1990: 435-446.

10. Robeck TR, Steinman KJ, Yoshioka M, Jensen E, O'Brien JK, Katsumata E, Gili C, McBain JF, Sweeney J, Monfort SL. Estrous cycle characterisation and artificial insemination using frozen-thawed spermatozoa in the bottlenose dolphin (Tursiops truncatus). Reproduction 2005; 129: 659-674. [Medline] [CrossRef]

11. Robeck TR, Steinman KJ, Greenwell M, Ramirez K, Van Bonn W, Yoshioka M, Katsumata E, Dalton L, Osborn S, O'Brien JK. Seasonality, estrous cycle characterization, estrus synchronization, semen cryopreservation, and artificial insemination in the Pacific white-sided dolphin (Lagenorhynchus obliquidens). Reproduction 2009; 138: 391-405. [Medline] [CrossRef]

12. Robeck TR, Steinman KJ, Gearhart S, Reidarson TR, McBain JF, Monfort SL. Reproductive physiology and development of artificial insemination technology in killer whales (Orcinus orca). Biol Reprod 2004; 71: 650-660. [Medline] [CrossRef]

13. Kasuya T. Finless porpoise Neophocaena phocaenoides (G. Cuvier, 1829). In: Ridgway SH, Harrison R (eds.), Handbook of Marine Mammals Vol. 6: the Second Book of Dolphins and the Porpoises. London: Academic Press; 1999: 411-442.

14. Jefferson TA, Wang JY. Revision of the taxonomy of finless porpoises (genus Neophocaena): the existence of two species. J Mar Anim Ecol 2011; 4: 3-16.

15. Yoshida H, Shirakihara M, Takemura A, Shirakihara K. Development, sexual dimorphism, and individual variation in the skeleton of the finless porpoise, Neophocaena phocaenoides, in the coastal waters of western Kyushu, Japan. Mar Mamm Sci 1994; 10: 266-282. [CrossRef]

16. Yoshida H, Yoshioka M, Shirakihara M, Chow S. Population structure of finless porpoises (Neophocaena phocaenoides) in coastal waters of Japan based on mitochondrial DNA sequences. J Mammal 2001; 82: 123-130. [CrossRef]

17. Kasuya T, Kureha K. The population of finless porpoise in the Inland Sea of Japan. Sci Rep Whales Res Inst 1979; 31: 1-44.

18. Kasuya T, Tobayama T, Saiga T, Kataoka T. Perinatal growth of delphinoids: information from aquarium reared bottlenose dolphins and finless porpoises. Sci Rep Whales Res Inst 1986; 37: 85-97.

19. Furata M, Kataoka T, Sekido M, Yamamoto K, Tsukuda O, Yamashita T. Growth of the finless porpoise Neophocaena phocaenoides (G. Cuvier, 1829) from the Ise Bay, central Japan. Ann Rep Toba Aquarium 1989; 1: 89-102.
20. Shirakihara M, Takemura A, Shirakihara K. Age, growth and reproduction of the finless porpoise, Neophocaena phocaenoides, in the coastal waters of western Kyushu, Japan. Mar Mamm Sci 1993; 9: 392-406. [CrossRef]

21. Kita S, Yoshioka M, Kashiwagi M. Sexual maturity and serum and testes testosterone concentrations in short-finned pilot whales (Globicephala macrorhynchus). Fish Sci 1999 65: 878-883. [CrossRef]

22. Hao YJ, Chen DQ, Zhao QZ, Wang D. Serum concentrations of gonadotropins and steroid hormones of Neophocaena phocaenoides asiaeorientalis in middle and lower regions of the Yangtze River. Theriogenology 2007; 67: 673-680. [Medline] [CrossRef]

23. Chen D, Hao Y, Zhao Q, Wang D. Reproductive seasonality and maturity of male $\mathrm{Neo}-$ phocaena phocaenoides asiaeorientalis in captivity: a case study based on the hormone evidence. Mar Freshwat Behav Physiol 2006; 39: 163-173. [CrossRef]

24. Gwinner E. 1986. Circannual Rhythms. Springer-Verlag, Berlin.

25. Goldman BD. Mammalian photoperiodic system: formal properties and neuroendocrine mechanisms of photoperiodic time measurement. J Biol Rhythms 2001; 16: 283-301. [Medline] [CrossRef]

26. Goldman B, Gwinner E, Karsch FJ, Saunders D, Zucker I, Ball GF. Circannual rhythms and photoperiodism. In: Dunlap JC, Loros JJ, DeCoursey PJ (eds.), Chronobiology; Biological Timekeeping. Sunderland: Sinauer Associates; 2004: 107-142.

27. Shimizu I, Oishi T., editors. 2008. Rhythm Ecology. Tokai University Press, Tokyo (in Japanese).

28. Concannon PW, Parks JE, Roberts PJ, Tennant BC. Persistent free-running circannua reproductive cycles during prolonged exposure to a constant 12L:12D photoperiod in laboratory woodchucks (Marmota monax). Lab Anim Sci 1992; 42: 382-391. [Medline]

29. Jansen HT, Jackson GL. Circannual rhythms in the ewe: patterns of ovarian cycles and prolactin secretion under two different constant photoperiods. Biol Reprod 1993; 49: 627-634. [Medline] [CrossRef]

30. Heideman PD, Bronson FH. An endogenous circannual rhythm of reproduction in a tropical bat, Anoura geoffroyi, is not entrained by photoperiod. Biol Reprod 1994; 50 607-614. [Medline] [CrossRef]

31. Malpaux B, Migaud M, Tricoire H, Chemineau P. Biology of mammalian photoperiodism and the critical role of the pineal gland and melatonin. J Biol Rhythms 2001; 16: 336-347. [Medline] [CrossRef]

32. Hastings M, ONeill JS, Maywood ES. Circadian clocks: regulators of endocrine and metabolic rhythms. J Endocrinol 2007; 195: 187-198. [Medline] [CrossRef]

33. Yu X, Hao Y, Kot BCW, Wang D. Effect of photoperiod extension on the testicular sonographic appearance and sexual behavior of captive Yangtze finless porpoise (Neophocaena asiaeorientalis asiaeorientalis). Zool Stud 2016; 55: 24.

34. Reiter RJ. The melatonin rhythm: both a clock and a calendar. Experientia 1993; 49 654-664. [Medline] [CrossRef]

35. Oelschläger HHA, Oelschläger JS. Brain. In: Perrin WF, Würsig B, Thewissen JGM (eds.), Encyclopedia of Marine Mammals, Second ed. San Diego: Academic Press; 2009: 134-149.

36. Funasaka N, Yoshioka M, Suzuki M, Ueda K, Miyahara H, Uchida S. Seasonal difference of diurnal variations in serum melatonin, cortisol, testosterone and rectal temperature in Indo-Pacific bottlenose dolphins Tursiops aduncus. Aquat Mamm 2011; 37: 433-442. [CrossRef]

37. Panin M, Gabai G, Ballarin C, Peruffo A, Cozzi B. Evidence of melatonin secretion in cetaceans: plasma concentration and extrapineal HIOMT-like presence in the bottlenose dolphin Tursiops truncatus. Gen Comp Endocrinol 2012; 177: 238-245. [Medline] [CrossRef]

38. Ishikawa A, Sakamoto $\mathbf{H}$, Katagiri S, Takahashi $\mathbf{Y}$. Changes in sexual behavior and fecal steroid hormone concentrations during the breeding season in female Hokkaido brown bears (Ursus arctos yesoensis) under captive condition. J Vet Med Sci 2003; 65: 99-102. [Medline] [CrossRef]

39. Tsubota T, Kanagawa H. Annual changes in serum testosterone levels and spermatogenesis in the Hokkaido brown bear, Ursus arctos yesoensis. J Mammal Soc Jpn 1989; 14: $11-17$.

40. Hafez ESE. Study on the breeding season and reproduction of the ewe. J Agric Sci 1952; 42: 189-199. [CrossRef]

41. Urian KW, Duffield DA, Read AJ, Wells RS, Shell ED. Seasonality of reproduction in bottlenose dolphins, Tursiops truncatus. J Mammal 1996; 77: 394-403. [CrossRef] 